\title{
High cervical myelopathy due to bony craniovertebral junction anomalies (atlantoaxial dislocation) in pediatric population- clinical scoring system
}

\author{
Raj Kumar \\ Director \\ All-India Institute of Medical Sciences \\ Rishikesh, Uttrakhand.
}

\section{SUMMARY}

Bony craniovertebral junction anomalies are rare anomalies to cause high cervical myelopathy. Atlantoaxial dislocation (congenital) is one of the commonest bony anomaly in children presenting with high cervical compression. It is relatively common in India with an incidence of 5-8 / 1000. When the distance of atlas (anterior arch) is more than $3 \mathrm{~mm}$ ( $4 \mathrm{~mm}$ children) from odontoid process, it is called as Atlantoaxial dislocation (AAD) resulting into bony compression of high cervical cord. The patients may present with quadriparesis, sensory impairment in all limbs along with lower cranial nerve involvement. Because of lower medullary involvement the respiratory compromises are also frequent, posing a threat to life. Complex anatomy of foramen magnum, plethora of clinical conditions and atypical surgical approaches are responsible for poor outcome in these children. A new clinical scoring system for myelopathy was evolved in order to have an objective and precise grading of these cases preoperatively and postoperatively. The need of precise scoring system was felt to have reproducibility and easy applicability in children of craniovertebral junction anomalies in order to fetch even minimal improvement or deterioration following complex surgery. Motor functions, gait, sensory, sphincteric, respiratory function \& spasticity were the parameters included in study of scoring system. This study was done in 177 operated cases of AAD (67 patients, below 14 years of age included for statistical analysis). Their detailed clinical \& radiological evaluation was done preoperatively \& postoperatively. The Kumar \& Kalra high cervical myelopathy grading system was thus, introduced in literature. System was easy to use, interpret and was more sensitive

Correspondence : Prof (Dr.) Raj Kumar, Director, All-India Institute of Medical Sciences, Rishikesh, Uttrakhand 249201, E.Mail : rajkumar1959@gmail.com.

DR. S. JANAKI MEMORIAL ORATION delivered during NAMSCON 2015 at the All-India Institute of Medical Sciences, Patna. 
to the changes in neurological status. It helped neurosurgeons and neurologists globally to evaluate and prognosticate the cases of Atlantoaxial dislocation.

Keywords : Pediatric, atlantoaxial dislocation, CV Junction anomalies, high cervical myelopathy.

The craniovertebral junction $(\mathrm{CVJ})$ is a complex transition zone between the cranial cavity and the rostral spinal column. Various conditions affect and destabilize this region; of these conditions, congenital atlantoaxial dislocation (AAD) is the most common anomaly $(1,2)$. The management of congenital CVJ anomalies is complex due to the relative difficulty in accessing the region, the critical relationship of neurovascular structures, and the intricate biomechanical issues involved, which revolve primarily around the attainment of neural decompression and stabilization (3). The difficulty accessing the CVJ relates primarily to ventrally compressing pathologies in which the transoral procedure is required to take out the offending bony element. In comparison, posterior access to the CVJ does not pose much of a problem but has threat of neural injury.

The most common age group affected by congenital AAD is the second and third decade; however, the incidence in the paediatric population is not uncommon. A wide variety of congenital anomalies of the CVJ occur due to an insult of bony and soft tissue elements, between the fourth and seventh week of intrauterine life (4). The clinical manifestations are most often delayed into the second and third decade because they are usually subtle and easily missed in children unless looked for specifically (1, 5). Moreover, this disease process is slowly progressive and manifests due to chronic compression of the cervicomedullary junction; it is usually brought about by triggering events such as trauma $(1,5,6)$. The criteria for diagnosis of AAD differ between children and adults. The normal atlas to dens interval is greater in children compared with adults; thus, AAD is diagnosed on the basis of atlantodental distance greater than $4 \mathrm{~mm}$ in patients younger than 9 years of age and greater than $3 \mathrm{~mm}$ for those 9 years of age or older (6). The management of these patients becomes even more difficult as a result of the general issues of managing children, which add to the typical issues of managing the complicated anomaly itself. There has been a progressive change in the approaches and techniques used for management (7). The outcome analysis performed to assess the surgical result has relied on Di Lorenzo's grading (DLG) system, which is a four-grade system based on functional dependence (Table 1) $(3,5,8)$. This has been the most widely used and accepted grading system to 
High cervical myelopathy due to bony craniovertebral junction anomalies 133

assess AAD patients undergoing treatment. The grading system has stood the test of time and has excellent reproducibility and inter observer reliability (7). However, although the DLG grading system is universally acceptable in adults, it may not be as readily applicable and useful in children. Children are unable to quantify their functional status and are otherwise dependent for their daily activities. Hence, it is difficult to access their functional disabilities caused by the disease process. Categorization according to disabilities as is done in the DLG may not be precise in this age group and lacks interobserver reliability and reproducibility.

Moreover, grading the patients into just four groups does not allow for the observation of subtle changes in neurological status. There is a large subset of patients who remain in the same grade even though they have subjective improvement or deterioration in their neurological status. It may be opined that a comprehensive and precise neurological examination may be more valuable in accessing the response to treatment. If a scoring system is developed that relies on these factors, it may be better reflective of progression of the disease course. Such a score should be detailed enough to recognize subtle neurological status changes but simple enough to be performed routinely. The purpose of the present study was to formulate a new scoring system based on comprehensive neurological examination and to assess its applicability in children compared with the DLG.

\section{Table 1 : Di Lorenzo's Grading system}

\begin{tabular}{|l|l|}
\hline Grade 1 & $\begin{array}{l}\text { Independent, without deficits except hyperreflexia or neck pain. } \\
\text { (Neurologically intact) }\end{array}$ \\
\hline Grade 2 & Independent for daily activities but having minor deficits (minor disability) \\
\hline Grade 3 & Partly dependent on others for their daily needs (moderate disability) \\
\hline Grade 4 & Totally dependent on others for daily needs (severe disability) \\
\hline
\end{tabular}

A study was done at SGPGIMS, Lucknow to introduce new scoring system; this was based on clinicoradiological evaluation of 177 cases operated over period of 14 years by single surgeon (RK). Statistical analysis was performed on children with age less than 14 years $(n=67)$. The diagnosis was based on a minimum atlantodental interval of 4 mm. The patients who had associated Chiari- I malformation, AAD and associated genetic syndromes, or follow up of Less than 12 months were excluded. The assessment of patients was done preoperatively and postoperatively \& follow up. The following points affecting the outcome were taken into consideration to fetch a new and precise scoring system 
for better evaluation of children suffering from congenital AAD (Table 2). There were 36 males and 31 females, with a mean age $9.36 \pm 3.51$ years (range 2-14 years). The results were compared with $\mathrm{Di}$ Lorenzo grading system.

Table 2 : Kumar \& Kalra scoring system (K \& K)

\begin{tabular}{|c|c|c|c|c|c|c|}
\hline Parameter & 1 & 2 & 3 & 4 & 5 & $\begin{array}{l}\begin{array}{l}\text { Total } \\
\text { score }\end{array} \\
\end{array}$ \\
\hline $\begin{array}{l}\text { Motor } \\
\text { power }\end{array}$ & $\begin{array}{l}\text { Contraction } \\
\text { w/o } \\
\text { movement } \\
\text { or plegia }\end{array}$ & $\begin{array}{l}\text { Movement } \\
\text { with } \\
\text { gravity }\end{array}$ & $\begin{array}{l}\text { Movement } \\
\text { against } \\
\text { gravity }\end{array}$ & $\begin{array}{l}\text { Movement } \\
\text { against } \\
\text { resistance }\end{array}$ & $\begin{array}{l}\text { Normal } \\
\text { power }\end{array}$ & 5 \\
\hline Gait & $\begin{array}{l}\text { Wheel } \\
\text { chair } \\
\text { bound or } \\
\text { bed ridden }\end{array}$ & $\begin{array}{l}\text { Restricted } \\
\text { mobility } \\
\text { despite aid }\end{array}$ & $\begin{array}{l}\text { Mobility } \\
\text { using aid }\end{array}$ & $\begin{array}{l}\text { Slight } \\
\text { disturbance, } \\
\text { no aid } \\
\text { required }\end{array}$ & Normal & 5 \\
\hline $\begin{array}{l}\text { Sensory } \\
\text { involvement }\end{array}$ & $\begin{array}{l}\text { Total loss } \\
\text { of function }\end{array}$ & $\begin{array}{l}\text { Restriction } \\
\text { of function } \\
\text { of daily } \\
\text { living }\end{array}$ & $\begin{array}{l}\text { Significant } \\
\text { involvement } \\
(>25 \%) \text { but } \\
\text { no } \\
\text { dysfunction } \\
\text { of daily } \\
\text { living }\end{array}$ & insignificant & $\begin{array}{l}\text { No sensory } \\
\text { loss }\end{array}$ & 5 \\
\hline $\begin{array}{l}\text { Sphincter } \\
\text { involvement }\end{array}$ & $\begin{array}{l}\text { Retention } \\
\text { requiring } \\
\text { indwelling } \\
\text { catheter }\end{array}$ & $\begin{array}{l}\text { Occasional } \\
\text { CIC } \\
\text { required } \\
\text { with } \\
\text { hesitancy }\end{array}$ & $\begin{array}{l}\text { Hesitancy } \\
\text { with } \\
\text { residual } \\
\text { urine not } \\
\text { requiring } \\
\text { catheter }\end{array}$ & $\begin{array}{l}\text { Hesitancy } \\
\text { but no } \\
\text { residual } \\
\text { urine }\end{array}$ & Normal & 5 \\
\hline Spasticity & $\begin{array}{l}\text { Affected } \\
\text { part rigid in } \\
\text { flexion or } \\
\text { extension }\end{array}$ & $\begin{array}{l}\text { Passive } \\
\text { movement } \\
\text { difficult }\end{array}$ & $\begin{array}{l}\text { Passive } \\
\text { movement } \\
\text { easy }\end{array}$ & $\begin{array}{l}\text { Slight } \\
\text { increase in } \\
\text { tone }\end{array}$ & Normal & 5 \\
\hline $\begin{array}{l}\text { Respiratory } \\
\text { difficulty }\end{array}$ & $\begin{array}{l}\text { Requires } \\
\text { assisted } \\
\text { respiration }\end{array}$ & $\begin{array}{l}\text { Dyspnoea } \\
\text { at rest }\end{array}$ & $\begin{array}{l}\text { Dyspnoea } \\
\text { on mild } \\
\text { exertion }\end{array}$ & $\begin{array}{l}\text { Dyspnoea } \\
\text { on moderate } \\
\text { exertion, } \\
\text { unable to do } \\
\text { active work }\end{array}$ & Normal & 5 \\
\hline
\end{tabular}


High cervical myelopathy due to bony craniovertebral junction anomalies 135

\section{Disability Grading :}

67 patients, treated surgically for $\mathrm{AAD}$ and having age less than 14 years, included in this study. They were assessed with the DLG and Kumar and Kalra $(K \& K)$ scores pre-and postoperatively (Table 3 and 4). The patients were divided into four grades according to the $\mathrm{K} \& \mathrm{~K}$ scores, with grade 1 patients having score from 25 to 30 , Grade 2 patients having score from 19 to 24 , Grade 3 patients having score from 13 to 18 and Grade 4 patients having score from 6 to 12 points. Most of the patients had poor grades. Using the DLG scoring system, there were $26(38.8 \%)$ patients in Grade 4 and seven $(10.4 \%)$ patients in Grade 3 preoperatively. The maximum postoperative improvement was witnessed in the Grade 4 patients, with as many as 23 patients showing improvement from their preoperative grades. Overall, $47.8 \%$ of the patients showed improvement and $10.4 \%$ showed deterioration. There was a high percentage $(41.8 \%)$ of patients who showed stabilization of their grades. When the K\&K scoring system was used on these patients, most $(65.7 \%)$ of the patients were rated as Grade 2 preoperatively. The number of patients $(n=13)$ in preoperative Grade 1 was also high. Only three patients were rated as Grade 4 preoperatively, and none remained in this group postoperatively. Overall, improvement was observed in the majority $(n=55)$ of the patients; fewer patients had deterioration $(n=6)$. Thus, stabilization of neurological status was seen in $41.8 \%$ of patients using the DLG score and in only $8.9 \%$ of the patients using the K\&K score. Although $47.8 \%$ of the patients showed improvement using the DLG scoring system, a very high percentage $(82.1 \%)$ of patients showed improvement using the K\&K score. Out of the 28 patients who had shown stabilization of their neurological status using the DLG score, 23 patients showed an improvement in scores when assessed by the K\&K score, two patients showed the stabilization of their scores, and three had deteriorated from their preoperative scores. The minimum improvement was observed in those with symptoms of weakness $(n=49)$ and spasticity $(n=47)$, which were the earliest symptoms to improve. The symptoms most resistant to treatment were respiratory $(n=7)$ and sphincter symptoms $(n=6)$. To establish the objective criteria of reliability and reproducibility of the proposed score, we analyzed each patient's DLG and K\&K scores preoperatively and compared them with their most recent follow-up scores and outcome. The statistical significance was ascertained by calculating $\mathrm{p}$-value using logistic regression and by measuring the positive predictive values for each score. The results are listed in Table 5. 
Table 3 : Outcome analysis based on Di Lorenzo's grading system

\begin{tabular}{|l|l|l|l|l|l|}
\hline Grade & $\begin{array}{l}\text { Pretreatment, } \\
\mathbf{n = 6 7}(\mathbf{1 0 0 \%})\end{array}$ & $\begin{array}{l}\text { Posttreatment } \\
\mathbf{n}=\mathbf{6 7}(\mathbf{1 0 0 \% )}\end{array}$ & Improved (\%) & $\begin{array}{l}\text { Same } \\
\mathbf{( \% )}\end{array}$ & $\begin{array}{l}\text { Deteriorated } \\
\mathbf{( \% )}\end{array}$ \\
\hline I & $10(14.9)$ & $17(25.4)$ & 0 & 8 & 2 \\
\hline II & $24(35.8)$ & $19(28.4)$ & 8 & 14 & 2 \\
\hline III & $7(10.4)$ & $25(37.3)$ & 1 & 3 & 3 \\
\hline IV & $26(38.8)$ & $6(9)$ & 23 & 3 & 0 \\
\hline Total & & & $32(47.8)$ & $28(41.8)$ & $7(10.4)$ \\
\hline
\end{tabular}

Table 4 : Outcome analysis based on Kumar \& Kalra score

\begin{tabular}{|l|l|l|l|l|l|}
\hline Grade* & $\begin{array}{l}\text { Pretreatment, } \\
\mathbf{n = 6 7 ( 1 0 0 \% )}\end{array}$ & $\begin{array}{l}\text { Posttreatment } \\
\mathbf{n = 6 7}(\mathbf{1 0 0 \% )}\end{array}$ & Improved (\%) & Same (\%) & $\begin{array}{l}\text { Deteriorated } \\
\mathbf{( \% )}\end{array}$ \\
\hline I (25-30) & $13(19.4)$ & $17(25.4)$ & 11 & 1 & 1 \\
\hline II (19-24) & $44(65.7)$ & $45(67.2)$ & 34 & 5 & 5 \\
\hline III (13-18) & $7(10.4)$ & $5(7.5)$ & 7 & 0 & 0 \\
\hline IV (6-12) & $3(4.5)$ & 0 & 3 & 0 & 0 \\
\hline Total & & & $55(82.1)$ & $6(8.9)$ & $6(8.9)$ \\
\hline
\end{tabular}

*Numbers in parentheses in the first column represent the value of the total score using the Kumar and Kalra score.

Table 5: Predictability of score

\begin{tabular}{|l|l|l|l|l|l|}
\hline Score used & $\begin{array}{l}\text { Mean } \\
\text { pretreatment }\end{array}$ & $\begin{array}{l}\text { Mean follow } \\
\text { up value }\end{array}$ & P value & Exp (B) & $\begin{array}{l}\text { Predictive } \\
\text { value (\%) }\end{array}$ \\
\hline DLG & $2.73 \pm 1.14$ & $2.30 \pm 0.95$ & 0.714 & 1.094 & 52.2 \\
\hline K\&K & $19.91 \pm 4$ & $23.22 \pm 3.36$ & 0.000 & 0.218 & 82.1 \\
\hline
\end{tabular}

DLG- Di Lorenzo's grade; K\&K- Kumar \& Kalra score.

The incidence of AAD in pediatric age group is significant enough to deserve special and separate emphasis. Majority of children with AAD in our country reach neurosurgeons through referral system and thus usually present in poor grades. After surgery, it has been observed that although majority of them show subjective improvement, a large number stay in same grade as their pre operative grade when DLG scoring system is used for assessment $(1,5)$. Furthermore there are patients who deteriorate \& may require surgery but stay in same grade. The DLG score used for adults is lacking in its reproducibility in children and does not truly reflect the gravity of disease process. Thus, it is not a very sensitive indicator of change in neurological status and cannot be reliable in children. The change in score and neurological status is better reflected by K\&K scores rather than 
High cervical myelopathy due to bony craniovertebral junction anomalies 137

DLG. Positive predictive value was better using $\mathrm{K} \& \mathrm{~K}$ score, and outcome analysis using $\mathrm{K} \& \mathrm{~K}$ score was statistically significant whereas the changes didn't bear statistically significant correlation using the DLG score $(\mathrm{p}=0.714)$. The advantages are the assessment and comparison of neurological status based on commonly occurring symptoms and signs, which are routinely assessed in neurological examination of such patients. The individual symptoms and signs can also be analysed and compared individually in terms of their severity and significance. Thus, both an overall status of function and individual symptom is known. The score is based on multitude of factors and hence is more sensitive. It is also more suited for statistical analysis. The score may very well be used for adult patients as the parameters used are common to adults also. Furthermore, after exclusion of respiratory parameters, it can also be used for myelopathy in other areas of spine.

To conclude, $\mathrm{K} \& \mathrm{~K}$ scoring system is easy to use and interpret, and is more sensitive to the changes in neurological status of patients than the currently used DLG system (9).

\section{REFERENCES:}

1. Kumar R, Kalra SK (2007). Pediatric atlantoaxial dislocation: nuances in management. J Pediatr Neurol 5:1-8.
2. Tuite GF, Veres R, Crockard HA, Sell D (1996). Pediatric trans oral surgery: indications, complications, and long term outcome. J Neurosurg 84:573583.

3. Kumar R, Nayak SR(2002). Management of pediatric congenital atlanto axial dislocation: A report of 23 cases from northern India. Pediatr Neurosurg 36:197-208.

4. Menezes AH (1998). Emroyology, development and classification. In: Surgery of the craniovertebral junction : Dickman CA, Spetzler RF, Sonntag VK (eds), New York : Thieme, 3-12.

5. Kumar R, Kalra KS (2007). Management concerns of pediatric congenital atlantoaxial dislocation in developing milieu. Pan ArabJ Neurosurg 11:28-37.

6. Behari S, Kalra SK, Kiran Kumar MV, Salunke P, Jaiswal AK, Jain VK (2007). Chiari malformation associated with atlanto-axial dislocation: focusing on the anterior cervico-medullary compression. Acta Neurochir (Wien) 149: 41-50.

7. Sumi M, Kataoka O, Ikeda M, Sawamura S, Uno K, Siba R (1997). Atlantoaxial dislocation. A follow up study of surgical results. Spine 22:759-764. 
138 Raj Kumar

8. Di Lorenzo N ( 1992$)$. Craniocervical junction

9. Kumar R, Kalra SK, Mahapatra malformation treated by transoral approach. A survey of 25 cases with emphasis on postoperative instability and outcome. Acta Neurochir (Wien) 118: 112-116.

AK (2007). A clinical scoring system for neurological assessment of high cervical myelopathy: measurements in pediatric patients with congenital atlantoaxial dislocations. Neurosurgery 61: 987-994. 


\section{Instructions to Authors}

The Annals of the National Academy of Medical Sciences (India), appearing quarterly welcomes the submission of original contributions in all topics of biomedical sciences. Submission of a manuscript for publication in this journal implies that it has not been published and is not under consideration for publication elsewhere.

Review articles will be featured only by invitation. In the case of a multiauthor submission, the contribution of each author must be clearly stated. The authors must declare conflict of interest, if any.

Three copies of the manuscript and a $\mathrm{CD}$ containing the manuscript complete with tables and figures should be submitted to: The Editor. Annals of the National Academy of Medical Sciences (India), NAMS House, Ansari Nagar, Mahatma Gandhi Marg, New Delhi-110 029.

\section{Preparation of Manuscript}

Type the manuscript on one side of bond paper of standard size with $2.5 \mathrm{~cm}$ margin all around in double spacing throughout, including the title page, text, acknowledgement, references, tables and legends to illustrations.

\section{Title}

The title page should carry (1)the title of the article; (2) a short running title of not more than 40 characters;(3) name of each author: first name, middle initial and surname: (4) name of the department(s) and institution(s) to which the work is attributed; (5) name and address of the author responsible for correspondence.

\section{Text}

The second page should carry an abstract of not more than 150 words and should state the purpose of study, basic procedures main findings and the principal conclusions. Below the summary three to ten key words or short phrases that will assist indexers should be provided. The third page should begin with the main text which should usually, but not necessarily, be divided into sections with headings: Introduction, Methods, Results and Discussion. In Discussion, emphasis should be given to the new and important aspects of the study and conclusions. The data given in the Results should not be repeated. The Discussion should include the implications of the findings and their limitation and observations should be related to other relevant studies. Conclusions should be linked with the goals of the study but unqualified statements and conclusions not completely supported by the data should be avoided. At the end of the text under Acknowledgement(s), persons who have made substantial contributions to the study may be acknowledged.

A running title of 10-12 words should be given. 


\section{References}

References to literature cited should be numbered by arabic numerals in parenthesis in the text. At the end of the text on a new page the list of references by numbers as cited in the text should be provided. The style of the examples as given below should be used. The title of the journals should be abbreviated according to the style used in Index Medicus and printed in its January issue each year. Some examples are given below:

\section{Journals}

Standard journal article

List all authors when six or less; when seven or more, list only first three and add et al. You CH, Lee KY, Chey WY a nd Menguy R ( $\left.19 \begin{array}{lll}9 & 8 & 0\end{array}\right)$. Electrogastrographic study of patients with unexplained nausea, bloating and vomiting. Gastroenterology 78: 311314.

\section{Corporate author}

The Royal Marsden Hospital BoneMarrow Transplantation Team (1977). Failure of syngeneic bone-marrow graft without preconditioning in post hepatitis marrow aplasia. Lancet 2: 242-244.

\section{No author given}

Anonymous (1981). Coffee drinking and cancer of the pancreas (Editorial). Br Med J 283: 628

\section{Books and Monographs}

Personal author(s)

Eisen HN (1974). Immunology: An Introduction to Molecular and Cellular Principles of the Immune Response. $5^{\text {th }}$ cd. New York: Harper and Row, 406416.

Editor, compiler, chairman as author Dausset J and Colombani J eds. (1973).Histocompatibility Testing 1972Copenhagen: Munksgaard, 12-18.

\section{Chapter in a book}

Weinstein L and Swartz MN (1974). Pathogenic properties of invading microorganisms, in: Pathologic Physiology: Mechanisms of Disease. Sodeman WA Jr and Sodeman WA (eds), Philadelphia: WB Saunders. 457-472.

\section{Legends for Illustrations}

Type legends of illustrations and figures double spaced, starting on a separate page, with arabic numerals corresponding to the illustrations. When symbols, arrows, numbers, or letters are used to identify parts of the illustration, identify and explain each one clearly in the legend. Explain internal scale and identify method of staining in photomicrographs.

Off Prints: A maximum of twenty-five offprints of the article will be provided free of charge on request if there is only one author. If the article has two or more authors, maximum of fifty off prints will be provided on request free of charge. Request for further copies should be sent to the Editor, Annals of the NAMS (India). 